\title{
Detection of dengue group viruses by fluorescence in situ hybridization
}

Vincent Raquin ${ }^{1}$, Martin Wannagat ${ }^{1,2}$, Karima Zouache ${ }^{3}$, Catherine Legras-Lachuer ${ }^{1}$, Claire Valiente Moro ${ }^{1}$ and Patrick Mavingui ${ }^{*}$

\begin{abstract}
Background: Dengue fever (DF) and dengue hemorrhagic fever (DHF) represent a global challenge in public health. It is estimated that 50 to 100 million infections occur each year causing approximately 20,000 deaths that are usually linked to severe cases like DHF and dengue shock syndrome. The causative agent of DF is dengue virus (genus Flavivirus) that comprises four distinct serotypes (DENV-1 to DENV-4). Fluorescence in situ hybridization (FISH) has been used successfully to detect pathogenic agents, but has not been implemented in detecting DENV. To improve our understanding of DENV infection and dissemination in host tissues, we designed specific probes to detect DENV in FISH assays.
\end{abstract}

Methods: Oligonucleotide probes were designed to hybridize with RNA from the broadest range of DENV isolates belonging to the four serotypes, but not to the closest Flavivirus genomes. Three probes that fit the criteria defined for FISH experiments were selected, targeting both coding and non-coding regions of the DENV genome. These probes were tested in FISH assays against the dengue vector Aedes albopictus (Diptera: Culicidae). The FISH experiments were led in vitro using the C6/36 cell line, and in vivo against dissected salivary glands, with epifluorescence and confocal microscopy.

Results: The three 60-nt oligonucleotides probes DENV-Probe A, B and C cover a broad range of DENV isolates from the four serotypes. When the three probes were used together, specific fluorescent signals were observed in C6/36 infected with each DENV serotypes. No signal was detected in either cells infected with close Flavivirus members West Nile virus or yellow fever virus. The same protocol was used on salivary glands of Ae. albopictus fed with a DENV-2 infectious blood-meal which showed positive signals in the lateral lobes of infected samples, with no significant signal in uninfected mosquitoes.

Conclusion: Based on the FISH technique, we propose a way to design and use oligonucleotide probes to detect arboviruses. Results showed that this method was successfully implemented to specifically detect DENV in a mosquito cell line, as well as in mosquito salivary glands for the DENV-2 serotype. In addition, we emphasize that FISH could be an alternative method to detect arboviruses in host tissues, also offering to circumvent the discontinuity of antibodies used in immunofluorescent assays.

Keywords: Dengue, Virus, Fluorescence In Situ Hybridization, Aedes albopictus

\footnotetext{
* Correspondence: patrick.mavingui@univ-lyon1.fr

1UMR CNRS 5557 Ecologie Microbienne, Université Lyon 1, 43 boulevard du

11 Novembre 1918, Villeurbanne cedex 69622, France

Full list of author information is available at the end of the article
} 


\section{Background}

Dengue fever (DF) is the most common arthropod-borne human viral disease, affecting populations of mainly tropical and sub-tropical countries. The geographic area of DF transmission has expanded considerably during recent decades, and the number of cases reported has increased more than 30-fold since the 1960s [1]. More than 50 million people are infected annually and a third of the world population is at risk of contracting the disease [2].

DF and dengue hemorrhagic fever (DHF) are caused by dengue virus (DENV), an arbovirus (arthropod-borne virus) belonging to the Flavivirus genus that comprises other medically important viruses such as yellow fever virus (YFV), West Nile virus (WNV), tick-borne encephalitis virus (TBEV) and Japanese encephalitis virus (JEV) [3]. The DENV nucleocapsid contains a singlestranded, positive-sense RNA genome of approximately $11 \mathrm{~kb}$ in length. Four antigenically distinct serotypes (DENV-1 to DENV-4) are known, defined according to cell-surface antigens detected using various serological methods [4,5]. Nucleic acid sequencing showed that within serotypes, genetically distinct groups called genotypes exist whose sequences diverge at given regions of the genome [6].

DENV are maintained in nature within two cycles. In the sylvatic cycle, non-human primates are the reservoirs and the virus is transmitted by arboreal mosquito vectors, such as Aedes furcifer and Aedes luteocephalus who have been identified as probable vectors in Senegal [7-9]. The human cycle involves highly anthropophilic vectors, mostly Aedes aegypti and Aedes albopictus, with humans as the only known reservoir and amplification host $[10,11]$. Tools are available to study DENV, including virus isolation that allows retrieval of particles from host samples [12], and quantitative RT-PCR to identify serotypes or genotypes and estimate virus density [13]. In addition, serological assays were developed to diagnose DENV infection among vertebrate hosts [14]. However, these methods did not allow direct visualization of DENV RNA or particles inside infected samples. Thus, they need to be completed with an in situ detection to fully understand the viral infection process and to explore the temporal and spatial tropism of DENV in hosts and reservoirs. Standard DENV in situ detection relies on direct targeting of virus particles using serotype-specific antibodies [15]. In humans, immunological detection of DENV in samples obtained from DF/DHF patients revealed virus tropism for liver, spleen, kidney, lung and phagocytic cells [16]. In mosquitoes, an immunodetection approach made it possible to decipher the DENV time course, called the extrinsic incubation period (EIP), time between ingestion of an infectious blood-meal to the infection of the salivary glands and release of the virus into the saliva [17].
Fluorescence in situ hybridization (FISH) is a detection method classically employed to target nucleic acids (RNA and DNA) within cells and tissues using a fluorochrome-labelled probe complementary to the target that is then observed by fluorescence microscopy [18]. The increasing range of available fluorochromes, the development of new bioinformatics tools assisting probe design, and improvements in fluorescence microscopy and imaging, have contributed to the extensive application of FISH in monitoring microbes in complex environments [19]. One advantage of FISH, along with accuracy and adaptability, is the possibility to combine several oligonucleotide probes. FISH and derivative techniques are therefore ideal when it is necessary to detect multiple target microorganisms in the same samples [20]. In addition, FISH can be combined to standard detection methods like Indirect Immunofluorescence Antibody Assay (IFA), thus providing a better detection of targets $[21,22]$. It also represents a useful alternative when antibodies are unavailable or inefficient for a given organism. Few studies have described the use of FISH techniques to monitor different virus taxa [23-25] and no probes are as yet available for DENV. For these reasons, the aim of the study was to develop a FISH-based method, from the design of oligonucleotide probes to the final detection of the four DENV serotypes, including the widest possible range of DENV isolates.

\section{Methods}

\section{Ethics statement}

Anti-DENV hyper-immune ascetic fluid, used as primary antibodies in virus titration assays, was produced in accordance with French and European regulations on care and protection of laboratory animals at the Institut Pasteur that has accreditation from the French Ministry of Agriculture [see permit numbers at http://webcampus. pasteur.fr/jcms/c_97619/agrements-des-animaleries].

This study was approved by the relative IACUC at the Institut Pasteur.

\section{Probe design}

Probe design was based on the method of Jabado et al. [26], modified as follows. Briefly, the 3 ' and 5 ' untranslated regions (UTR), and coding regions of the DENV genome were recovered from GenBank (release 101, issue date 28, September 2009) [27]. Pfam-A was used to group the selected protein sequences into families according to domain similarity [28]. NCR sequences or those not grouped in Pfam-A families were clustered by CD-Hit [29] at a similarity threshold of $80 \%$. For protein sequence motifs, the most conserved non-overlapping regions of 23 amino acids in length were selected using the statistics of the hidden Markov model and the motifs were mapped to their underlying nucleic sequences. 
From the resulting database, sequences of candidate probes were shortlisted using the following criteria to maximize specificity: melting temperature $\geq 65^{\circ} \mathrm{C}$; GC content between $40 \%$ and $60 \%$; no homopolymer of 5 or more of the same nucleotide; no repeats of 10 or more nucleotides; and stem loop length $\leq 11$ nt. The specificity of all selected sequences was checked using the Basic Local Alignment Search tool (BLAST) querying the NCBI nucleotide database [30]. To further optimize hybridization, only sequences (maximum length, 60 nucleotides) showing a 75\% overall similarity or forming 15 consecutive base pairs with a target sequence were synthesized (Life Technologies, Saint-Aubin, France). Entropy, cross-hybridization, and the absence of possible secondary structure, like hairpins, were checked using the online tool DINAMELT [31].

\section{Viruses}

The dengue strains DENV-1 FGA/89, DENV-2 Jam, DENV-3 PaH88/881 and DENV-4 63632 were obtained from the Centre de Ressources Biologiques de l'Institut Pasteur (CRBIP, Paris, France). DENV-2 Bangkok, YFV and WNV strains were provided by the Virology Department of Institut Pasteur (Paris, France). Details of the virus strains are listed in Table 1 . Viral stocks were produced on Aedes cell lines as previously described [32-36].

\section{Cell culture and virus infection}

The C6/36 cell line derived from Aedes albopictus larvae [39] was grown at $28^{\circ} \mathrm{C}$ in Leibovitz's 15 (L-15) medium (Life Technologies) containing 10\% foetal bovine serum (FBS) (PAA, Les Mureaux, France), 50 units $/ \mathrm{mL}$ penicillin, $50 \mu \mathrm{g} / \mathrm{mL}$ streptomycin and $1 \mathrm{X}[7.5 \mathrm{mg} / \mathrm{L}$ Glycine, $8.9 \mathrm{mg} / \mathrm{L}$ L-Alanine, $13.2 \mathrm{mg} / \mathrm{L} \mathrm{L}$-Aspargine, $13.3 \mathrm{mg} / \mathrm{L}$ L_Aspartic acid, $14.7 \mathrm{mg} / \mathrm{L}$ L-Glutamic acid, $11.5 \mathrm{mg} / \mathrm{L}$ L-Proline, $10.5 \mathrm{mg} / \mathrm{L}$ L-Serine] non essential amino acids (Life Technologies). Twenty-four hours before virus infection, $5 \times 10^{5}$ cells were allowed to attach to a sterile cover slip in shell vials (Sterilin, Newport, United Kingdom). Cell samples were then infected in triplicate with each DENV serotype or YFV and WNV strains at a multiplicity of infection (MOI) of 3. Uninfected cells were used as negative controls. Virus stocks were diluted in appropriate volumes of L-15 medium supplemented with $2 \%$ FBS, and layered onto $80 \%$-confluent cell monolayers for $1 \mathrm{hr}$ at $28^{\circ} \mathrm{C}$. After virus adsorption the inoculum was removed, $1 \mathrm{~mL}$ of medium with $2 \%$ FBS was added, and cells were incubated at $28^{\circ} \mathrm{C}$. At 5 days postinfection (pi), supernatants were harvested and stored at $-80^{\circ} \mathrm{C}$ for virus titration. Cells were washed once with PBS and fixed for $20 \mathrm{~min}$ at room temperature in freshly prepared $4 \%$ formaldehyde (Sigma-Aldrich, Lyon, France) in PBS, then rinsed three times in PBS.

To control the replication of the different virus strains used, $1 \times 10^{6}$ cells were inoculated into 6-well plates and incubated at $28^{\circ} \mathrm{C}$ two days before infection. Virus infection in duplicate at a MOI of 3 was done as described above.

\section{Mosquito rearing and oral infection}

The mosquito Ae. albopictus ALPROV originating from La Reunion was reared in standard conditions as reported [40]. For experimental infections, $1 \mathrm{~mL}$ of DENV-2 suspension (Bangkok strain) was mixed with 2 $\mathrm{mL}$ of washed rabbit erythrocytes (New Zealand White, Charles River) supplemented with ATP at final concentration of $5 \mathrm{mM}$ (Sigma-Aldrich). Seven-day-old female mosquitoes, starved for $24 \mathrm{~h}$, were fed with infectious blood at a titer of $10^{7.5} \mathrm{FFU}$ (Fluorescent Focus Units) per $\mathrm{mL}$ from a glass feeder as described [41]. Females fed with non-infected blood were used as controls. Fully engorged females were transferred to cardboard containers at $28 \pm 11^{\circ} \mathrm{C}$ and fed with $10 \%$ sucrose. At day 14 pi, females were sacrificed and surface-disinfected in $70 \%$ ethanol and rinsed twice in sterile PBS. Salivary glands were removed from insects by dissection under a binocular microscope then deposited on a sterile glass cover slip previously coated with $40 \mu \mathrm{L}$ of $0.01 \%$ poly-L-lysine (Sigma-Aldrich) in PBS. Salivary gland samples were fixed for $20 \mathrm{~min}$ in freshly prepared $4 \%$ formaldehyde in PBS in a shell vial, then washed 3 times in PBS and hybridized to probes as described below.

\section{Fluorescence in situ hybridization}

PBS was removed from fixed cells or tissues (as above) and $1 \mathrm{~mL}$ of hybridization buffer $(5 \mathrm{X}[750 \mathrm{mM} \mathrm{NaCl}$,

Table 1 Strains of Flavivirus used in this study

\begin{tabular}{|c|c|c|c|c|c|c|c|}
\hline Genus & Virus & Strain & Locality & Year & Sample & GenBank accession number & Reference \\
\hline \multirow[t]{7}{*}{ Flavivirus } & Dengue serotype 1 & FGA/89 & French Guiana & 1989 & Human & AF226687.2 & [32] \\
\hline & Dengue serotype 2 & Jam/N.1409 & Jamaica & 1983 & Human & M20558.1 & [33] \\
\hline & Dengue serotype 2 & Bangkok & Thailand & 1974 & Human & Unavailable & {$[34]$} \\
\hline & Dengue serotype 3 & $\mathrm{PaH} 881 / 88$ & Thailand & 1988 & Human & S67858.1 & {$[35]$} \\
\hline & Dengue serotype 4 & 63632 & Senegal & 1983 & Human & Unavailable & {$[36]$} \\
\hline & Yellow fever virus & Unavailable & Senegal & 1979 & Human & Unavailable & {$[37]$} \\
\hline & West Nile virus & Unavailable & France & 2001 & Horse & AF418554.1 & {$[38]$} \\
\hline
\end{tabular}


$75 \mathrm{mM}$ Na-citrate, pH 7] SSC (Euromedex), 50\% formamide, $200 \mathrm{mg} / \mathrm{mL}$ dextran sulfate, $250 \mu \mathrm{g} / \mathrm{mL}$ poly(A), $250 \mu \mathrm{g} / \mathrm{mL}$ salmon sperm DNA, $0.1 \mathrm{M}$ dithiothreitol (DTT), 0.5X Denhardt's solution (Sigma-Aldrich), 250 $\mu \mathrm{g} / \mathrm{mL}$ tRNA) containing $10 \mathrm{ng}$ of each DENV probe, labeled at the $5^{\prime}$ end with AlexaFluor ${ }^{\circledR} 488$, was added. After incubation, the hybridization buffer was discarded and the samples were rinsed once in $1 \mathrm{X}[150 \mathrm{mM}$ $\mathrm{NaCl}, 15 \mathrm{mM}$ Na-citrate, $\mathrm{pH}$ 7] SSC, $10 \mathrm{mM}$ DTT at room temperature. Further washes were done at $55^{\circ} \mathrm{C}$ for $15 \mathrm{~min}$ each, twice in $1 \mathrm{X}$ [150 $\mathrm{mM} \mathrm{NaCl}, 15 \mathrm{mM}$ Na-citrate, $\mathrm{pH}$ 7] SSC, $10 \mathrm{mM}$ DTT and twice in $0.5 \mathrm{X}$ [75 mM NaCl, $7.5 \mathrm{mM}$ Na-citrate, pH 7] SSC, $10 \mathrm{mM}$ DTT. Finally, samples were rinsed three times in PBS, and each coverslip was carefully taken from the shell vial and mounted on a glass slide with $2.5 \mu \mathrm{L}$ of DAPI (4, 6'diamidino-2-phenylindole, dihydrochloride) at $1 \mu \mathrm{g} / \mathrm{mL}$ in glycerol/PBS (v/v). Slides were stored overnight at $4^{\circ} \mathrm{C}$ in the dark before microscopic observation.

\section{Fluorescence microscopy}

Slides were viewed under an epifluorescence (Axio Imager Z1, Zeiss) or a confocal microscope (LSM510, Zeiss). Exposure time for each laser (to excite DAPI and AlexaFluor ${ }^{\circledR} 488$ ) was standardized among samples. Images for each laser were taken separately then merged using the free-access software ImageJ MacBiophotonics (release 1.46, 32-bit, downloaded from www. rsb.info.nih.gov/ij/).

\section{Virus titration}

Fluorescent focus assays (FFA) were used to estimate virus infectious titer on C6/36 cells. Two days before infection, $3 \times 10^{5}$ cells were placed in 96-well microplates and allowed to grow at $28^{\circ} \mathrm{C}$. Confluent monolayers were infected with $50 \mu \mathrm{L}$ of 10 -fold serial dilutions of viral suspension in L-15 medium supplemented with $2 \%$ FBS. To allow viral adsorption, the microplates were incubated for $1 \mathrm{~h}$ at $28^{\circ} \mathrm{C}$ in $2 \%$ FBS L-15 medium with gentle shaking every $15 \mathrm{~min}$. Then an overlay medium $(150 \mu \mathrm{L})$ composed of L-15 medium with $10 \%(\mathrm{v} / \mathrm{v}) \mathrm{FBS}$ and 3.2\% (v/v) carboxymethyl cellulose (VWR, Pessac, France), was added. After 5 days at $28^{\circ} \mathrm{C}$, cells were fixed by overlaying $100 \mu \mathrm{L}$ of $4 \%$ formaldehyde in PBS for $20 \mathrm{~min}$ at room temperature. All the suspension was then gently removed and fixed cells were washed three times in PBS. For primary antibody staining, cells were incubated with mouse hyper-immune ascetic fluid (diluted 1:100 in PBS) specific to each virus for $45 \mathrm{~min}$ at $37^{\circ} \mathrm{C}$. After three washes with PBS, anti-mouse IgG FITC conjugate (Bio-Rad, Marnes-La-Coquette, France), diluted 1:80 in PBS, was added for $45 \mathrm{~min}$ at $37^{\circ} \mathrm{C}$. Cells were then rinsed three times in PBS and observed with an inverted fluorescent microscope (Zeiss) equipped with a FITC filter. Fluorescent foci of infected cells were counted under a $10 \times$ objective and virus titers were expressed as the number of FFU per $\mathrm{mL}$ [42].

\section{RNA extraction, reverse transcription and diagnostic PCR}

At 5 days pi, supernatants from infected cells in 6-well plates were removed. Cells were harvested and pelleted using a tabletop centrifuge, then stored at $-80^{\circ} \mathrm{C}$ until use. Total RNA was obtained using the Qiagen RNeasy Mini Kit (Qiagen, Courtaboeuf, France), according to the manufacturer's recommendations, first crushing the cell pellet with a pestle for $30 \mathrm{~s}$ in $350 \mu \mathrm{L}$ RLT buffer. Residual DNA was eliminated using the Turbo DNA-free kit as recommended by the manufacturer (Life Technologies).

RNA (100 ng) was reverse transcribed using $400 \mathrm{U}$ SuperScript III reverse transcriptase (Life Technologies) and $200 \mathrm{ng}$ of random primers in a $50-\mu \mathrm{L}$ reaction volume according to the manufacturer's recommendations. The resulting cDNA samples were treated with $10 \mathrm{U} / \mu \mathrm{L}$ RNase $\mathrm{H}$ (Life Technologies) for $20 \mathrm{~min}$ at $37^{\circ} \mathrm{C}$, then purified using a QIAquick PCR purification kit according to manufacturer's instructions (Qiagen).

To detect virus RNA, diagnostic PCR was done with Flavivirus-specific primers PF1S (5'-TGYRTBT AYAACATGATGGG-3') and PF2R-bis (5'-GTGTCCCA ICCNGCNGTRTC3') targeting an approximately 230-bp fragment of the NS5 gene [43]. The $25-\mu \mathrm{L}$ reaction mixture contained $40 \mathrm{ng}$ of cDNA template, $0.5 \mathrm{U}$ Taq polymerase, [20 mM Tris- $\mathrm{HCl}(\mathrm{pH} 8.4), 500 \mathrm{mM} \mathrm{KCl}]$ reaction buffer (both from Life Technologies), $1.5 \mathrm{mM}$ $\mathrm{MgCl}_{2}, 200 \mu \mathrm{M}$ of each dNTP and $200 \mathrm{nM}$ of each primer. PCR was performed in a T1 Thermocycler (Biometra) as follows: $95^{\circ} \mathrm{C}$ for $3 \mathrm{~min} ; 40$ cycles of $94^{\circ} \mathrm{C}$ for $1 \mathrm{~min}, 50^{\circ} \mathrm{C}$ for $1 \mathrm{~min}, 72^{\circ} \mathrm{C}$ for $1 \mathrm{~min}$; and $72^{\circ} \mathrm{C}$ for $10 \mathrm{~min}$. PCR products were checked by electrophoresis through 1\% agarose gel alongside a low-range DNA ladder (Fermentas, Courtaboeuf, France). Fragments of expected sizes were sequenced (Sanger sequencing).

\section{Results and discussion}

\section{In silico analysis of selected DENV probes}

The probe design strategy allowed a set of ten probes that fitted the criteria listed above to be obtained. We selected two probes with a GC content close to $50 \%$ and a lower number of hairpins, while targeting the broadest range of DENV isolates. Two oligonucleotide probes, designated DENV-ProbeA and DENV-ProbeB, which target respectively a fragment of a 3' untranslated region (UTR) and a fragment of the non-structural 3 (NS3) protein-encoding gene were first selected (Table 2). When analyzed against the NCBI nucleotide collection using BLASTn, with a word size of 7 , an expected threshold of 1,000 and a minimal e-value of 0.05 , the 
Table 2 DENV probe sequences

\begin{tabular}{llccc}
\hline & \multicolumn{1}{c}{ Sequence $\mathbf{( 5}$ ' to $\left.\mathbf{3}^{\prime}\right)$} & GC\% & Tm $\left({ }^{\circ} \mathbf{C}\right)$ & Hairpin DG \\
\hline DENV-ProbeA & GCCGGATTAAGCCATAGTACGGTAAGAGCTATGCTGCCTGTGAGCCCCGTCTGAGGACGT & 57 & 56.7 & -2 \\
\hline DENV-ProbeB & AGAAAATGACCAGTACATATTCACGGGCCAGCCTCTCAACAATGACGAGGACCATGCTCA & 48 & 48.3 & -1.8 \\
\hline DENV-ProbeC & ATGGTGCTTCACTGGGGAAAGAAATAACCAAATTCTAGAAGAAAACATGGAGGTTGAAAT & 37 & 36.7 & -0.9 \\
\hline
\end{tabular}

DENV-Probes A and B sequences matched with all DENV serotypes (Additional file 1: Figure S1). These results indicated that most of the sequences for each serotype present in GenBank would be detected by at least one of the two probes, except for DENV-4. Indeed, the specificity of the two probes for the DENV-4 serotype was relatively low, and matched few DENV-4 isolates. Although this result might be unexpected as there is relatively little genomic divergence between DENV serotypes [44], we found that DENV-4 is the serotype with the fewest sequences available in GenBank, which could partly explain the BLASTn results. To detect as many DENV isolates as possible, the DENV-ProbeC, which targets a fragment of the non-structural 2 (NS2) protein-encoding gene and matches with all sequenced complete genomes of DENV-4 (Table 3, Additional file 2: Figure S1), was added to the initial set of probes.

Using the BLASTn parameters described above, the three DENV probes were matched against the YFV (taxid: 11089), WNV (taxid: 11082), JEV (taxid: 11072), chikungunya virus (CHIKV, taxid: 337124) and Aedes (taxid: 7158) and no sequences were retrieved. These results indicated that in silico, no hybridization with these viruses could occur.

\section{Detection of DENV serotypes in infected cell cultures}

The FISH method using the three DENV-ProbeA, DENV-ProbeB, and DENV-ProbeC probes together was first tested using the well-characterized arboviruspermissive Ae. albopictus C6/36 cell line. The use of three probes simultaneously may lead to a considerable increase in the hybridizing signal, with no incidence on the level of the background signal [45]. After infection at

Table 3 Number of isolates targeted by the three DENV probes simultaneously

\begin{tabular}{lcccc}
\hline & DENV-1 & DENV-2 & DENV-3 & DENV-4 \\
\hline Isolates $^{\mathrm{a}}(\%)$ & $1279(98.8)^{\mathrm{b}}$ & $885(99.7)^{\mathrm{b}}$ & $654(99.8)^{\mathrm{b}}$ & $97(100)^{\mathrm{b}}$ \\
\hline e-value max & $9 \times 10^{-23}$ & $9 \times 10^{-5}$ & $9 \times 10^{-23}$ & $9 \times 10^{-23}$ \\
\hline e-value min & $1 \times 10^{-3}$ & $3 \times 10^{-3}$ & $1 \times 10^{-14}$ & $1 \times 10^{-21}$ \\
\hline Query max & 100 & 98 & 100 & 100 \\
\hline Query min & 90 & 85 & 98 & 98 \\
\hline Identity max & 100 & 100 & 100 & 100 \\
\hline Identity min & 98 & 94 & 98 & 73 \\
\hline
\end{tabular}

${ }^{a}$ Complete genome sequences only.

${ }^{b} \mathrm{NCBI}$ GenBank nucleotide database, release 189 of $15^{\text {th }}$ April 2012. a MOI of 3, green fluorescent dots corresponding to the hybridized probes with DENV RNA were observed in the cytoplasm of cells infected with each of the four DENV serotypes at 5 days pi (Figure 1). No green fluorescent signal was observed in the cytoplasm of uninfected control cells. Nuclei were strongly stained blue with DAPI with, in some cases, a faint green autofluorescence (Figure 1). This hybridization pattern was expected as members of the genus Flavivirus are known to replicate almost exclusively in the cytoplasm of infected cells [46,47]. Overall, these observations validate the choice of probes and the hybridization protocol.

To assess probe specificity towards DENV, we also infected cells with genetically closely related Flavivirus YFV and WNV, then hybridized with the three DENVProbeA, DENV-ProbeB, and DENV-ProbeC probes together as described above. As expected from in silico analyses, no green fluorescence was detected at day $5 \mathrm{pi}$, as was observed for uninfected cells (Figure 1). Flavivirus replication kinetics in C6/36 is known to reach the plateau phase at 5 or 6 days pi $[48,49]$. This shows that the DENV probes do not readily cross-hybridize with the most closely related viruses in insect cells.

To ensure that the absence of signal in the above YFV and WNV samples was not an artifact of defective viral infection, supernatants from the same cell cultures previously used in FISH were titrated for viruses. The infectious titers reached $5.6 \times 10^{11} \mathrm{FFU} / \mathrm{mL}$ for WNV, $2.2 \times$ $10^{11} \mathrm{FFU} / \mathrm{mL}$ for YFV and those of DENV1 to DENV-4 were comprised between 1.4 to $2.0 \times 10^{5} \mathrm{FFU} / \mathrm{mL}$ (positive controls). No fluorescent foci were counted for uninfected cell supernatants. In addition, the presence of viral RNA was ascertained by reverse transcription and PCR amplification using genus-specific primers. Bands of the expected size (230 bp) were obtained for all the six viruses from day 5 pi cultures (Figure 2) and sequencing of PCR products (data not shown) confirmed they belonged to the respective viruses tested, indicating that replication of each virus was productive in C6/36 infected cells.

\section{Monitoring of DENV in mosquito tissues}

The virus infection process in mosquitoes is very different from that in cell culture. To evaluate the usefulness of the DENV FISH probes, they were used to localize DENV in host tissues. Females of Ae. albopictus ALPROV from La Reunion fed with a DENV-2 Bangkok 


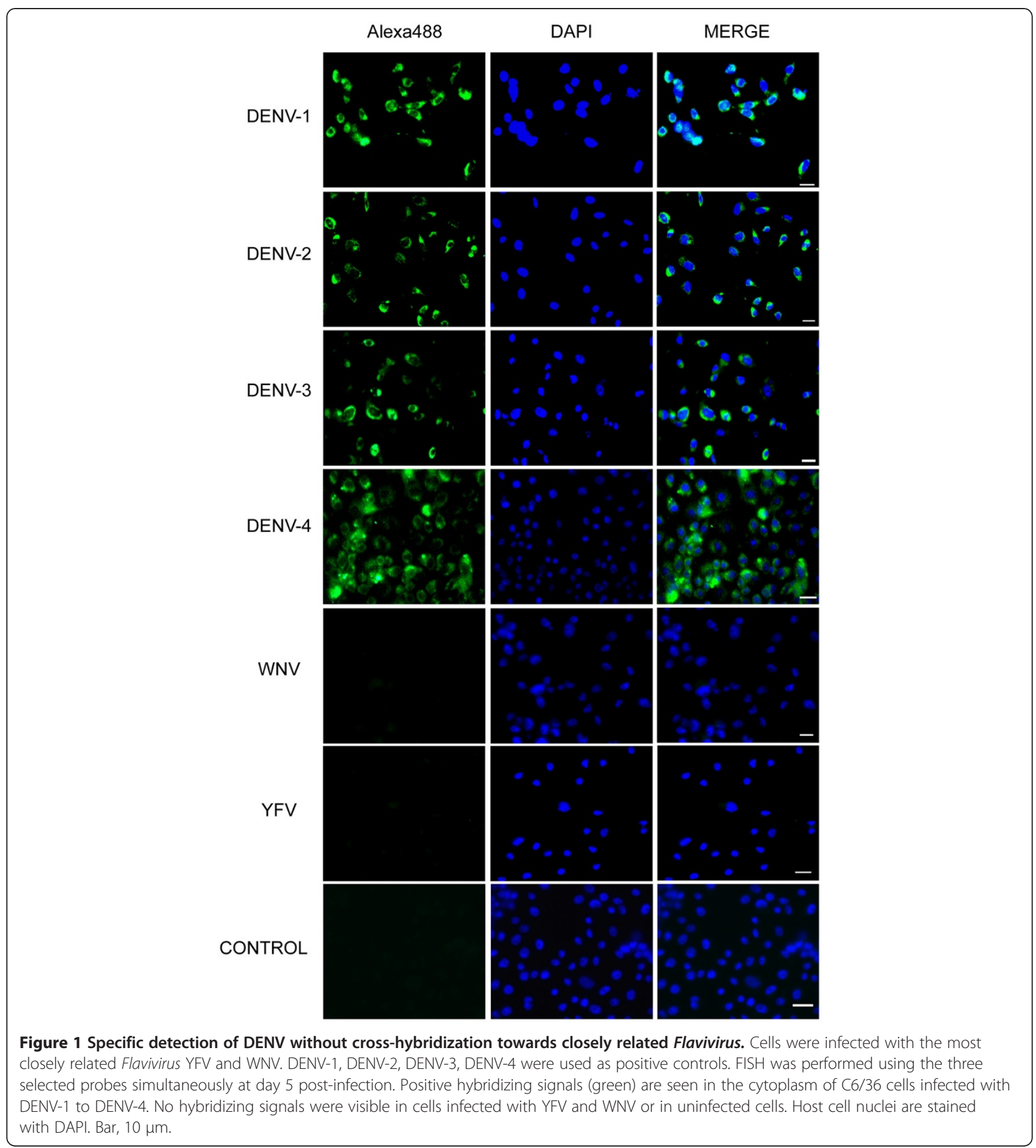

strain infectious blood-meal were dissected at 14 days pi. The DENV probes were designed to match with the largest number of DENV isolates as possible, within each serotype. As a consequence, we decided to use the Bangkok isolate of DENV-2 (Table 1) to infect Ae. albopictus, as we had experimental data on it's replication kinetic in this mosquito strain system in contrast to previously used DENV strains $[42,50]$.
The dissected salivary glands of infected females were hybridized with the three DENV-Probes, as described. Confocal microscopic images showed dots indicative of probe hybridization in the lateral lobes of DENVinfected females at 14 days pi (Figure 3). In contrast, no significant fluorescent signals were observed in organs of uninfected mosquitoes used as negative controls (Figure 3). This result confirmed that our probes 


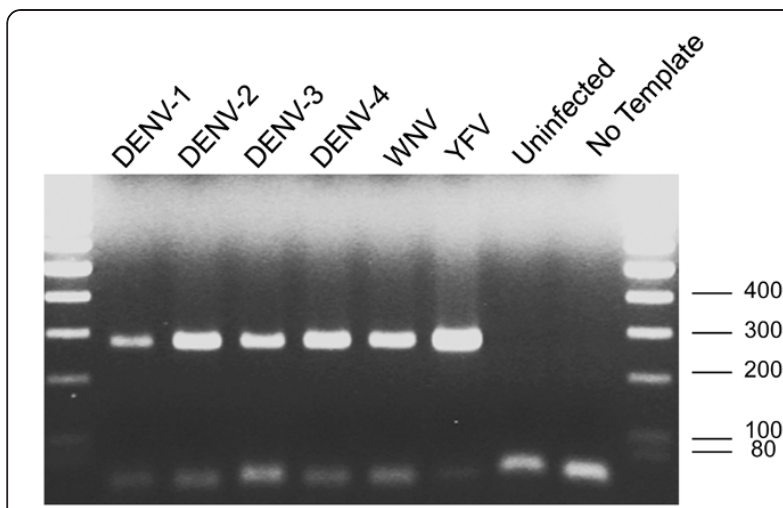

Figure 2 Diagnostic PCR of viral RNA in C6/36 cells. C6/36 cells were infected with DENV-1 to DENV-4, YFV or WNV and 5 days later RNA was extracted from cells and reverse transcribed. PCR was performed on the cDNA obtained to amplify a 230-bp fragment of the NS5 gene, conserved among Flavivirus. Fragments of the expected size were obtained for all the six viruses, but not for uninfected cells. Ladder Mass Ruler DNA Low Range (Fermentas) was used as size marker (bp).

could be used to detect DENV-2 in Ae. albopictus salivary glands after oral infection of the vector.

In the principal DENV vector Ae aegypti, a period of 7 to 10 days post-infection is necessary to reach maximum viral replication, allowing the virus particles to invade salivary glands [17]. Ae. albopictus is less competent for DENV, the incubation period to reach high RNA levels is longer and close to 14 days [50,51]. Moreover, the density of infectious DENV particles in the salivary glands was found to be weak in Ae. albopictus ALPROV strain, due to Wolbachia infection (Mousson et al., submitted). Despite this constraint, we were able to detect viral RNA in Ae. albopictus salivary glands at 14 days pi. This result shows that FISH is an efficient method that can be used even with complex material like mosquito organs.

To detect DENV in situ, the indirect Immunofluorescence Antibody Assay (IFA) is the standard method, with serotype specific antibodies commercially available [52]. However, IFA method targets antigenic proteins at the surface of viral particles whereas the FISH technique is based on the detection of viral RNA, two different labels of the viral cycle. The FISH method allows monitoring of DENV replicating genome during infection process and may represent a complementary method to IFA. Moreover, the literature provides numerous studies using FISH and IFA in combination [22,53,54]. In addition, we emphasize that FISH could be an alternative method to detect arboviruses in host tissues, also

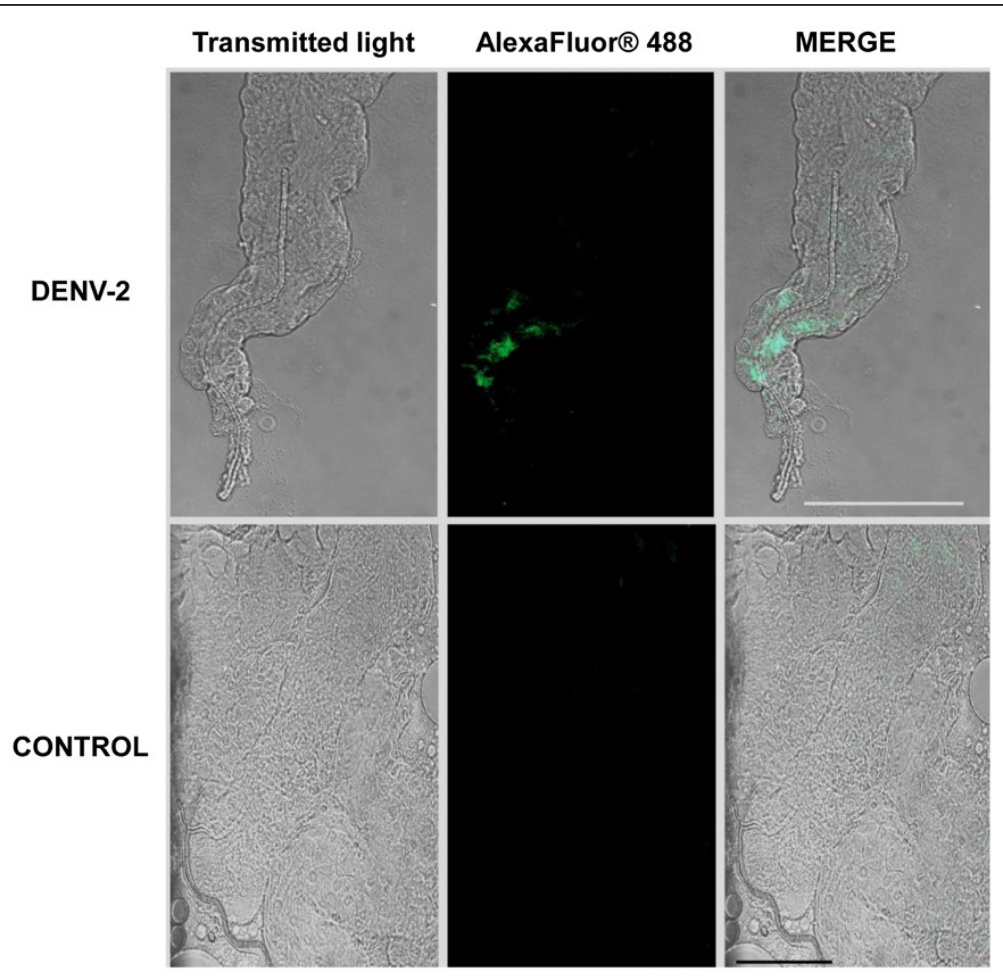

Figure 3 FISH detection of viral RNA in salivary glands of Aedes albopictus by confocal microscopy. FISH was carried out on salivary glands dissected from Ae. albopictus females at 14 days post-infection with blood-meals containing DENV-2 Bangkok strain, using the three DENV-Probes simultaneously. Viral RNA is detected (green) in the distal zone of the lobe close to the salivary duct. No signal was detected in control females engorged with an uninfected blood-meal. Bar, $500 \mu \mathrm{m}$. A global view of salivary glands is provided in the supplementary Figure S2. 
offering to circumvent the discontinuity of antibodies used in immunofluorescent assays.

\section{Conclusions}

In this study, oligonucleotide FISH was developed and used for the first time to detect replicating genomic DENV RNA. Viral RNAs were detected in both infected cell lines and salivary glands of the mosquito vector Ae. albopictus. As mentioned, Ae. albopictus is a less efficient vector of DENV than Aedes aegypti. Recent work has established that Wolbachia, a bacterial endosymbiont naturally present in Ae. albopictus, influences vector competence by interfering with viral infection and dissemination in mosquitoes [40,55]. This FISH approach could be useful to identify DENV tropism in the less efficient vector Ae. albopictus. Furthermore, it could help to explain the bacterial influence on DENV dissemination, especially as we have already detected Wolbachia in mosquito tissues using the same FISH-based protocol presented here [56]. This could improve our comprehension of mosquito vectorial competence for DENV.

DENV replication begins with the synthesis of a negative intermediate RNA, which appears transiently double-stranded RNA (dsRNA ) for production of positive strands used in virion assembly [57]. dsRNA is considered as the true replicative intermediate form of DENV, and can be detected with specific antibodies [58]. The FISH technique could be used to discriminate positive and negative strands by designing specific probes, and eventually couple to IFA in order to detect every intermediate as well as viral proteins [59].

Cases of co-infection with multiple DENV serotypes [60] and chikungunya virus were reported in human [61,62] and in Ae. albopictus [63], the latter having the ability to simultaneously deliver DENV and CHIKV in its saliva [63]. These multiple infections, together with potential multipartite interactions, emphasize the importance in some circumstances of monitoring more than one infectious agent at a time [64]. This work provides a method to design oligonucleotide probes specific for a given DNA/RNA template, which may be useful for microorganisms for which no antibodies are available yet, as well as a unique hybridization protocol that has already been used to detect other types of microorganisms [56]. In this context, FISH could be an adapted alternative method for monitoring multiple biological agents in a given tissue.

\section{Additional files}

Additional file 1: Figure S1. Alignment of DENV-Probes on genomic RNA sequence of DENV isolates. ClustalW Multiple Alignment was performed to align DENV-ProbeA, DENV-ProbeB and DENV-ProbeC against some well-targeted DENV RNA sequences. As mentioned in the text, very few isolates of DENV-4 were targeted by probes A and B. The mismatch numbers for DENV-ProbeA with DENV-4 were high and distorted alignment, so DENV-4 was removed from the analysis. As the DENV-ProbeC specifically targets serotype 4, only alignment on DENV-4 sequence isolates is presented.

Additional file 2: Figure S2. Epifluorescence microscopy showing morphology of Aedes albopictus salivary glands. The cell nuclei appear in green after labelling by SYTOX. SD, salivary duct; LL: Lateral Lobe; ML: Median Lobe. Bar, $500 \mu \mathrm{m}$.

\section{Abbreviations}

Arbovirus: Arthropod borne virus; DAPI: 4', 6'-diamidino-2-phenylindole, dihydrochloride; DENV: Dengue virus; dsRNA: Double-stranded RNA; DTT: Dithiothreitol; EIP: Extrinsic incubation period; FBS: Foetal bovine serum; FFA: Fluorescent focus assay; FFU: Fluorescent forming unit;

FISH: Fluorescence In Situ Hybridization; IFA: Indirect immunofluorescence antibody assay; JEV: Japanese encephalitis virus; L-15: Leibovitz's 15 medium; LTR: Long terminal repeat; MOI: Multiplicity of infection; NCR: Non coding region; PBS: Phosphate buffered saline; PI: Post infection; SSC: Saline-sodium citrate; TBEV: Tick-borne encephalitis virus; UTR: Untranslated region;

WNV: West-nile virus; YFV: Yellow fever virus.

\section{Competing interests}

The authors declare that they have no competing interests.

\section{Author's contributions}

VR, CVM, and PM conceived the work. VR, MV, KZ, CVM and PM designed and performed the experiments. VR, MV, KZ, CLL, CVM and PM analyzed the results. VR, CVM, PM wrote the paper in collaboration with other authors. All authors read and approved the final version of the manuscript.

\section{Acknowledgements}

We thank Marie Vazeille and Anna-Bella Failloux at the Institut Pasteur in Paris for supplying us with the YFV and WNV strains. We also thank Nelly Burlet and Claire Prigent-Combaret for assistance with microscopy. We acknowledge the contribution of the BSL3 platform of SFR BioSciences Gerland Lyon Sud (UMS3444/US8) as well as the DTAMB platform and the Centre Technologique des Microstructures (CTH) of the FR41 Bio-

Environment and Health (University Lyon 1), and the Lyon Science Transfert (University of Lyon 1). VR was funded by a PhD fellowship from the French Ministère de l'Education Nationale. This work was partially funded by the grants ANR-2010-BLAN-170101 (ImmunSymbArt), ACIP A-10-2009 and FRBCD-AOOI-07-12, and was carried out within the framework of the GDRIs "Biodiversity and Infectious Diseases" and "Biodiversité et Développement Durable".

\section{Author details}

1UMR CNRS 5557 Ecologie Microbienne, Université Lyon 1, 43 boulevard du 11 Novembre 1918, Villeurbanne cedex 69622, France. ²PRABI, Pôle RhôneAlpes de Bioinformatique, Villeurbanne, France. ${ }^{3}$ Institut Pasteur, Department of Virology, Arboviruses and Insect Vectors, 25-28 rue du Dr Roux, Paris cedex 15 75724, France.

Received: 24 August 2012 Accepted: 25 October 2012 Published: 30 October 2012

\section{References}

1. Guzman MG, Halstead SB, Artsob H, Buchy P, Farrar J, Gubler DJ, Hunsperger E, Kroeger A, Margolis HS, Martínez E, Nathan MB, Pelegrino JL, Simmons C, Yoksan S, Peeling RW: Dengue: a continuing global threat. Nat Rev Microbiol 2010, 8:S7-16.

2. Dengue: guidelines for diagnosis, treatment, prevention and control-new edition World Health Organization. Geneva; 2009 http://whqlibdoc.who.int/ publications/2009/9789241547871_eng.pdf.

3. Fauquet CM, Fargette D: International Committee on Taxonomy of Viruses and the 3,142 unassigned species. Virol J 2005, 2:64.

4. Sabin AB: Research on dengue during World War II. Am J Trop Med Hyg 1952, 1:30-50. 
5. Hammon WM, Rudnick A, Sather GE: Viruses associated with epidemic hemorrhagic fevers of the Philippines and Thailand. Science 1960, 131:1102-1103.

6. Rico-Hesse R: Molecular evolution and distribution of dengue viruses type 1 and 2 in nature. Virology 1990, 174:479-493.

7. Diallo M, Ba Y, Sall AA, Diop OM, Ndione JA, Mondo M, Girault L, Mathiot C: Amplification of the sylvatic cycle of dengue virus type 2, Senegal, 1999-2000: entomologic findings and epidemiologic considerations. Emerging Infect Dis 2003, 9:362-367.

8. Diallo M, Sall AA, Moncayo AC, Ba Y, Fernandez Z, Ortiz D, Coffey LL, Mathiot C, Tesh RB, Weaver SC: Potential role of sylvatic and domestic African mosquito species in dengue emergence. Am J Trop Med Hyg 2005, 73:445-449.

9. Robin Y, Cornet M, Heme G, Le Gonidec G: Isolement du virus de la dengue au Sénégal. Annales de l'Institut Pasteur / Virologie 1980, 131:149-154.

10. Vasilakis N, Cardosa J, Hanley KA, Holmes EC, Weaver SC: Fever from the forest: prospects for the continued emergence of sylvatic dengue virus and its impact on public health. Nat Rev Microbiol 2011, 9:532-541.

11. Kamgang B, Nchoutpouen E, Simard F, Paupy C: Notes on the blood-feeding behavior of Aedes albopictus (Diptera: Culicidae) in Cameroon. Parasit Vectors 2012, 5:57.

12. Rosen L, Gubler D: The use of mosquitoes to detect and propagate dengue viruses. Am J Trop Med Hyg 1974, 23:1153-1160.

13. Johnson BW, Russell BJ, Lanciotti RS: Serotype-specific detection of dengue viruses in a fourplex real-time reverse transcriptase PCR assay. J Clin Microbiol 2005, 43:4977-4983.

14. Fry SR, Meyer M, Semple MG, Simmons CP, Sekaran SD, Huang JX, McElnea C, Huang C-Y, Valks A, Young PR, Cooper MA: The Diagnostic Sensitivity of Dengue Rapid Test Assays Is Significantly Enhanced by Using a Combined Antigen and Antibody Testing Approach. PLoS Negl Trop Dis 2011, 5:e1199.

15. Peeling RW, Artsob H, Pelegrino JL, Buchy P, Cardosa MJ, Devi S, Enria DA, Farrar J, Gubler DJ, Guzman MG, Halstead SB, Hunsperger E, Kliks S, Margolis HS, Nathanson CM, Nguyen VC, Rizzo N, Vázquez S, Yoksan S: Evaluation of diagnostic tests: dengue. Nat Rev Microbiol 2010, 8:S30-38.

16. Jessie K, Fong MY, Devi S, Lam SK, Wong KT: Localization of dengue virus in naturally infected human tissues, by immunohistochemistry and in situ hybridization. J Infect Dis 2004, 189:1411-1418.

17. Salazar MI, Richardson JH, Sánchez-Vargas I, Olson KE, Beaty BJ: Dengue virus type 2: replication and tropisms in orally infected Aedes aegypti mosquitoes. BMC Microbiol 2007, 7:9.

18. Rudkin GT, Stollar BD: High resolution detection of DNA-RNA hybrids in situ by indirect immunofluorescence. Nature 1977, 265:472-473.

19. Wagner M, Haider S: New trends in fluorescence in situ hybridization for identification and functional analyses of microbes. Curr Opin Biotechnol 2012, 23:96-102.

20. Volpi EV, Bridger JM: FISH glossary: an overview of the fluorescence in situ hybridization technique. Biotechniques 2008, 45:385-386. 388, 390 passim.

21. Lucy FE, Graczyk TK, Tamang L, Miraflor A, Minchin D: Biomonitoring of surface and coastal water for Cryptosporidium, Giardia, and human-virulent microsporidia using molluscan shellfish. Parasitol Res 2008, 103:1369-1375.

22. Smith Jj, Gunasekera Ts, Barardi Crm, Veal D, Vesey G: Determination of Cryptosporidium parvum oocyst viability by fluorescence in situ hybridization using a ribosomal RNA-directed probe. J Appl Microbiol 2004, 96:409-417.

23. Brass V, Gosert $R$, Moradpour D: Investigation of the hepatitis $C$ virus replication complex. Methods Mol Biol 2009, 510:195-209.

24. Uphoff CC, Denkmann SA, Steube KG, Drexler HG: Detection of EBV, HBV, HCV, HIV-1, HTLV-I and -II, and SMRV in human and other primate cell lines. J Biomed Biotechnol 2010, 2010:904767.

25. Kobiler O, Brodersen P, Taylor MP, Ludmir EB, Enquist LW: Herpesvirus replication compartments originate with single incoming viral genomes. MBio 2011, 2.

26. Jabado OJ, Liu Y, Conlan S, Quan PL, Hegyi H, Lussier Y, Briese T, Palacios G, Lipkin WI: Comprehensive viral oligonucleotide probe design using conserved protein regions. Nucleic Acids Res 2008, 36:e3.

27. Benson DA, Karsch-Mizrachi I, Lipman DJ, Ostell J, Wheeler DL: GenBank. Nucleic Acids Res 2008, 36:D25-30
28. Finn RD, Tate J, Mistry J, Coggill PC, Sammut SJ, Hotz H-R, Ceric G, Forslund K, Eddy SR, Sonnhammer ELL, Bateman A: The Pfam protein families database. Nucleic Acids Res 2008, 36:D281-288.

29. Li W, Godzik A: Cd-hit: a fast program for clustering and comparing large sets of protein or nucleotide sequences. Bioinformatics 2006, 22:1658-1659.

30. Kanz C, Aldebert P, Althorpe N, Baker W, Baldwin A, Bates K, Browne P, van den Broek A, Castro M, Cochrane G, Duggan K, Eberhardt R, Faruque N, Gamble J, Diez FG, Harte N, Kulikova T, Lin Q, Lombard V, Lopez R, Mancuso R, McHale M, Nardone F, Silventoinen V, Sobhany S, Stoehr P, Tuli MA, Tzouvara K, Vaughan R, Wu D, Zhu W, Apweiler R: The EMBL Nucleotide Sequence Database. Nucleic Acids Res 2005, 33:D29-33.

31. Markham NR, Zuker M: DINAMelt web server for nucleic acid melting prediction. Nucleic Acids Res 2005, 33:W577-581.

32. Santos CN Dd, Frenkiel MP, Courageot MP, Rocha CF, Vazeille-Falcoz MC, Wien MW, Rey FA, Deubel V, Desprès P: Determinants in the envelope $E$ protein and viral RNA helicase NS3 that influence the induction of apoptosis in response to infection with dengue type 1 virus. Virology 2000, 274:292-308

33. Deubel V, Kinney RM, Trent DW: Nucleotide sequence and deduced amino acid sequence of the structural proteins of dengue type 2 virus, Jamaica genotype. Virology 1986, 155:365-377.

34. Vazeille-Falcoz M, Mousson L, Rodhain F, Chungue E, Failloux AB: Variation in oral susceptibility to dengue type 2 virus of populations of Aedes aegypti from the islands of Tahiti and Moorea, French Polynesia. Am J Trop Med Hyg 1999, 60:292-299.

35. Chungue E, Deubel V, Cassar O, Laille M, Martin PM: Molecular epidemiology of dengue 3 viruses and genetic relatedness among dengue 3 strains isolated from patients with mild or severe form of dengue fever in French Polynesia. J Gen Virol 1993, 74(Pt 12):2765-2770.

36. Chungue $\mathrm{E}$, Cassar O, Drouet MT, Guzman MG, Laille M, Rosen L, Deubel V: Molecular epidemiology of dengue- 1 and dengue-4 viruses. J Gen Virol 1995, 76:1877-1884.

37. Rodhain F, Hannoun C, Jousset FX, Ravisse P: Isolation of the yellow fever virus in Paris from 2 imported human cases. Bull Soc Pathol Exot Filiales 1979, 72:411-415.

38. Murgue B, Murri S, Zientara S, Durand B, Durand JP, Zeller H: West Nile outbreak in horses in southern France, 2000: the return after 35 years. Emerging Infect Dis 2001, 7:692-696.

39. Igarashi A: Isolation of a Singh's Aedes albopictus cell clone sensitive to Dengue and Chikungunya viruses. J Gen Virol 1978, 40:531-544.

40. Mousson L, Martin E, Zouache K, Madec Y, Mavingui P, Failloux AB: Wolbachia modulates Chikungunya replication in Aedes albopictus. Mol Ecol 2010, 19:1953-1964.

41. Zouache K, Michelland RJ, Failloux A-B, Grundmann GL, Mavingui P: Chikungunya virus impacts the diversity of symbiotic bacteria in mosquito vector. Mol Ecol 2012, 21:2297-2309.

42. Blagrove MSC, Arias-Goeta C, Failloux A-B, Sinkins SP: Wolbachia strain wMel induces cytoplasmic incompatibility and blocks dengue transmission in Aedes albopictus. Proc Natl Acad Sci USA 2012, 109:255-260.

43. Moureau G, Temmam S, Gonzalez JP, Charrel RN, Grard G, de Lamballerie X: A real-time RT-PCR method for the universal detection and identification of flaviviruses. Vector Borne Zoonotic Dis 2007, 7:467-477.

44. Vasilakis N, Weaver SC: The history and evolution of human dengue emergence. Adv Virus Res 2008, 72:1-76.

45. Zwirglmaier K: Fluorescence in situ hybridisation (FISH)-the next generation. FEMS Microbiol Lett 2005, 246:151-158.

46. Westaway EG, Mackenzie JM, Kenney MT, Jones MK, Khromykh AA Ultrastructure of Kunjin virus-infected cells: colocalization of NS1 and NS3 with double-stranded RNA, and of NS2B with NS3, in virus-induced membrane structures. J Virol 1997, 71:6650-6661.

47. Grun JB, Brinton MA: Dissociation of NS5 from cell fractions containing West Nile virus-specific polymerase activity. J Virol 1987, 61:3641-3644.

48. Lim PY, Louie KL, Styer LM, Shi PY, Bernard KA: Viral pathogenesis in mice is similar for West Nile virus derived from mosquito and mammalian cells. Virology 2010, 400:93-103.

49. Pierro DJ, Salazar MI, Beaty BJ, Olson KE: Infectious clone construction of dengue virus type 2 , strain Jamaican 1409 , and characterization of a conditional E6 mutation. J Gen Virol 2006, 87:2263-2268. 
50. Vazeille M, Rosen L, Mousson L, Failloux A-B: Low oral receptivity for dengue type 2 viruses of Aedes albopictus from Southeast Asia compared with that of Aedes aegypti. Am J Trop Med Hyg 2003, 68:203-208.

51. Zhang M, Zheng X, Wu Y, Gan M, He A, Li Z, Liu J, Zhan X: Quantitative analysis of replication and tropisms of Dengue virus type 2 in Aedes albopictus. Am J Trop Med Hyg 2010, 83:700-707.

52. Henchal EA, McCown JM, Seguin MC, Gentry MK, Brandt WE: Rapid identification of dengue virus isolates by using monoclonal antibodies in an indirect immunofluorescence assay. Am J Trop Med Hyg 1983, 32:164-169.

53. Larsen P, Nielsen JL, Otzen D, Nielsen PH: Amyloid-Like Adhesins Produced by Floc-Forming and Filamentous Bacteria in Activated Sludge. Appl Environ Microbiol 2008, 74:1517-1526.

54. Bednarska M, Bajer A, Sinski E, Girouard AS, Tamang L, Graczyk TK: Fluorescent in situ hybridization as a tool to retrospectively identify Cryptosporidium parvum and Giardia lamblia in samples from terrestrial mammalian wildlife. Parasitol Res 2007, 100:455-460.

55. Moreira LA, Iturbe-Ormaetxe I, Jeffery JA, Lu G, Pyke AT, Hedges LM, Rocha BC, Hall-Mendelin S, Day A, Riegler M, Hugo LE, Johnson KN, Kay BH, McGraw EA, van den Hurk AF, Ryan PA, O'Neill SL: A Wolbachia symbiont in Aedes aegypti limits infection with dengue, Chikungunya, and Plasmodium. Cell 2009, 139:1268-1278.

56. Zouache K, Voronin D, Tran-Van V, Mousson L, Failloux A-B, Mavingui P: Persistent Wolbachia and cultivable bacteria infection in the reproductive and somatic tissues of the mosquito vector Aedes albopictus. PLoS One 2009, 4:e6388.

57. Lindenbach BD, Rice CM: Molecular biology of flaviviruses. Adv Virus Res 2003, 59:23-61.

58. Welsch S, Miller S, Romero-Brey I, Merz A, Bleck CKE, Walther P, Fuller SD, Antony C, Krijnse-Locker J, Bartenschlager R: Composition and three-dimensional architecture of the dengue virus replication and assembly sites. Cell Host Microbe 2009, 5:365-375.

59. Vyboh K, Ajamian L, Mouland AJ: Detection of viral RNA by fluorescence in situ hybridization (FISH). J Vis Exp 2012, 5:e4002

60. Bharaj P, Chahar HS, Pandey A, Diddi K, Dar L, Guleria R, Kabra SK, Broor S: Concurrent infections by all four dengue virus serotypes during an outbreak of dengue in 2006 in Delhi. India. Virol J 2008, 5:1.

61. Hapuarachchi HAC, Bandara KBAT, Hapugoda MD, Williams S, Abeyewickreme W: Laboratory confirmation of dengue and chikungunya co-infection. Ceylon Med J 2008, 53:104-105.

62. Schilling S, Emmerich P, Günther S, Schmidt-Chanasit J: Dengue and Chikungunya virus co-infection in a German traveller. J Clin Virol 2009, 45:163-164.

63. Leroy EM, Nkoghe D, Ollomo B, Nze-Nkogue C, Becquart P, Grard G, Pourrut X, Charrel R, Moureau G, Ndjoyi-Mbiguino A, De-Lamballerie X: Concurrent chikungunya and dengue virus infections during simultaneous outbreaks, Gabon, 2007. Emerging Infect Dis 2009, 15:591-593.

64. Sivaram A, Barde P, Gokhale M, Singh D, Mourya D: Evidence of co-infection of chikungunya and densonucleosis viruses in C6/36 cell lines and laboratory infected Aedes aegypti (L.) mosquitoes. Parasit Vectors 2010, 3:95.

doi:10.1186/1756-3305-5-243

Cite this article as: Raquin et al:: Detection of dengue group viruses by fluorescence in situ hybridization. Parasites \& Vectors 2012 5:243.

\section{Submit your next manuscript to BioMed Central and take full advantage of:}

- Convenient online submission

- Thorough peer review

- No space constraints or color figure charges

- Immediate publication on acceptance

- Inclusion in PubMed, CAS, Scopus and Google Scholar

- Research which is freely available for redistribution

Submit your manuscript at www.biomedcentral.com/submit 